University of Montana

ScholarWorks at University of Montana

Numerical Terradynamic Simulation Group

Publications

Numerical Terradynamic Simulation Group

4-1989

\title{
Estimation of Regional Surface Resistance to Evapotranspiration from NDVI and Thermal-IR AVHRR Data
}

\author{
Ramakrishna R. Nemani \\ The University of Montana \\ Steven W. Running \\ University of Montana - Missoula
}

Follow this and additional works at: https://scholarworks.umt.edu/ntsg_pubs

\section{Let us know how access to this document benefits you.}

\section{Recommended Citation}

Nemani, Ramakrishna R. and Running, Steven W. (1989). Journal of Applied Meteorology, 28, 276-284.

http://dx.doi.org/10.1175/1520-0450(1989)028<0276:EORSRT>2.0.C0;2

This Article is brought to you for free and open access by the Numerical Terradynamic Simulation Group at ScholarWorks at University of Montana. It has been accepted for inclusion in Numerical Terradynamic Simulation Group Publications by an authorized administrator of ScholarWorks at University of Montana. For more information, please contact scholarworks@mso.umt.edu. 


\title{
Estimation of Regional Surface Resistance to Evapotranspiration from NDVI and Thermal-IR AVHRR Data
}

\author{
RAMAKRISHNA R. NEMANI AND STEVEN W. RUNNING \\ School of Forestry. University of Montana. Missoula. Montana
}

(Manuscript received II April 1988, in final form 19 September 1988)

\begin{abstract}
Infrared surface temperatures from satellite sensors have been used to infer evaporation and soil moisture distribution over large areas. However, surface energy partitioning to latent versus sensible heat changes with surface vegetation cover and water availability. We tested a hypothesis that the relationship between surface temperature and canopy density is sensitive to seasonal changes in canopy resistance of conifer forests. Surface temperature $(T s)$ and canopy density were computed for a $20 \times 25 \mathrm{~km}$ forested region in Montana, from the NOAA / A VHRR for 8 days during the summer of 1985. A forest ecosystem model, FOREST-BGC, simulated canopy resistance $\left(\boldsymbol{R}_{\mathrm{c}}\right)$ for the same period.

For all eight days, surface temperatures had high association with canopy density, measured as Normalized Difference Vegetation Index (NDVI) $\left(R^{2}=0.73-0.91\right.$ ), implying that latent heat exchange is the major cause of spatial variations in surface radiant temperatures. The stope of $T$, and NDVI, $\sigma$, was sensitive to changes in canopy resistance on two contrasting days of canopy activity. The trajectory of $\sigma$ followed seasonal changes in canopy resistance simulated by the model. The relationship found between $\sigma$ and $R_{c}\left(R^{2}=0.92\right)$, was nonlinear, expected because $R_{c}$ values beyond $20 \mathrm{~s} \mathrm{~cm}^{-1}$ do not influence energy partitioning significantly. The slope of $T_{s}$ and NDVI, $\sigma$, could provide a useful parameterization of surface resistance in regional evapotranspiration research.
\end{abstract}

\section{Introduction}

Evapotranspiration (ET) is an important component of the earth's hydrologic cycle: on land surfaces, $60 \%$ of the precipitation received is expended through ET (Brutsaert 1986). Accurate information on ET is an essential element for solving energy and hydrologic cycles of the biosphere, as it provides a link between the two cycles. The significance of ET at the earth-atmosphere interface extends from the large-scale circulation of the planetary atmosphere, to the determination of water use by plants at a local level, down to water loss and carbon dioxide uptake of stomates in individual leaves (Jarvis and McNaughton 1986). ET can be adequately determined at leaf and plant levels: however, it is one of the least understood aspects of the hydrologic cycle at larger scales. This is, in part, due to the difficulty in assessing ET on a regional scale (Rasool and Bolle 1984).

ET on a large scale is usually computed as vapor loss from a surface assumed to be well watered, primarily driven by the physical environment. It is also known as potential ET (PET). However, research in the last three decades has established that surface properties such as soil moisture status and physiological

Corresponding author address: Prof. Steven W. Running, School of Forestry, University of Montana, Missoula, MT 59812. activity of the vegetation are equally important in the ET process, and that they tend to limit ET below the potential level. Two approaches are generally used to reduce PET down to actual ET. These are 1) the Priestley-Taylor (1972) factor $(\alpha)$ used as

$$
\mathrm{ET}=\alpha \mathrm{PET},
$$

where $\alpha$ decreases with decreasing soil moisture content, and 2) Monteith's resistance factor, $R_{c}$, incorporated into the Penman equation as

$$
\mathrm{LE}=\frac{s R_{n}+\rho_{c_{p}}\left(\mathrm{VPD} / R_{a}\right)}{s+\gamma\left(1+\left(R_{c} / R_{a}\right)\right)}
$$

where LE is latent heat flux, $R_{n}$ is net radiation, VPD is vapor pressure deficit $\left(e_{s}-e_{a}\right), \rho_{c}$, is heat capacity of air, $s$ is slope of the saturation vapor pressure curve at mean air temperature, $\gamma$ is psychrometric constant, $R_{a}$ is aerodynamic resistance, and $R_{c}$ is canopy resistance which is a function of vegetation stress and/or soil water stress. Though, conceptually the two approaches may appear quite different functionally both are the same (De Bruin 1983). However, the resistance approach has been very useful in explaining vegetational effects in plant-soil water simulation models, and also in diagnostic analyses of field data (McNaughton and Jarvis 1983). The aerodynamic resistance $R_{c}$ can be estimated adequately on a local scale, but parameterizing $R_{c}$ at a regional scale is extremely difficult 
because of the complex physiographic and geomorphic characteristics of many hydrologic systems.

The possibility of using satellite observations of the earth's reflected solar energy and emitted thermal energy to help understand energy and moisture fluxes at the earth's surface has been recognized previously (Idso et al. 1975: Price 198Z; Whitehead et al. 1986). Analysis of the energy budget at the earth surface using satellitederived temperatures has been used for relating ET and soil moisture to surface temperature from a bare surface (Seguin and Itier 1983: Carlson et al. 1981; Gurney and Camillo 1984; Abdellaoui et al. 1986). The influence of vegetation was incorporated into the above models, for the first time, by Wetzel and Atlas (1983) who applied a very simplified parameterization in a one-dimensional boundary layer/vegetation/ ground model using satellite temperatures over a large heterogeneous region. Recently, Taconet et al. (1986b), using a more elaborate formulation for vegetation based on Deardorff (1978), reported that canopy resistance $\left(R_{c}\right)$ can be estimated from thermal infrared remote sensing in conjunction with a simulation model. These models, physically elaborate but morphologically unrealistic in many ways for representing vegetation, require prior knowledge about many parameters that describe the surface. Most models of vegetation were developed for crops ( Taconet et al. 1986a; Cheevasuvit et al. 1985; Soer 1980), and cannot be readily applied to natural ecosystems such as conifer forests. Goward et al. (1985) suggested the possibility of using the rate of change in surface temperature with the amount of vegetation to describe surface characteristics. The underlying principle for such a technique is that surface temperature decreases with an increase in density of vegetation through latent heat transfer, though the decrease in surface temperature is modulated by the synoptic state of the atmosphere as well as the aerodynamic and canopy resistances operating at the surface.

The objective of this study is to test the hypothesis that seasonal trends in the relation between vegetation density and surface temperature derived from satellite sensors can represent seasonal changes in canopy resistance of conifer forests. Because a direct measurement of canopy resistance at regional scale is not possible, we will compare trends in the canopy densitysurface temperature ralation with simulation results from a process level ecosystem model of canopy $\mathrm{CO}_{2}$ and $\mathrm{H}_{2} \mathrm{O}$ exchange, FOREST-BGC, that has been developed from recent ecosystem analysis modeling research (Running and Coughlan 1988).

\section{Theoretical considerations}

The Penman-Monteith equation is frequently used for computing ET from vegetation [Eq. (2)]. It gives a one-dimensional description of the interrelationships between the physical environment and vegetation. For some types of vegetation (e.g., tall ) Eq. (2) can be further simplified by identifying the dominant mechanism in the ET process. We can separate Eq. 2 into energy and aerodynamic terms to determine their relative contribution to ET as follows:

$$
\mathrm{LE}=\frac{s R_{n}}{s+\gamma\left(1+\left(R_{c} / R_{a}\right)\right)}+\frac{\rho_{c_{e}}\left(\mathrm{VPD} / R_{a}\right)}{s+\gamma\left(1+\left(R_{c} / R_{a}\right)\right)}
$$

Tall canopies such as conifer forests are generally aerodynamically rough (Thom 1975), and experience lower boundary layer resistance compared to shorter vegetation (Stewart 1984). Such canopies are said to be tightly coupled to the air around them, and the air within the canopy is well coupled to the atmosphere overhead (Jarvis and McNaughton 1986). The evaporation rate in these cases is primarily controlled by the vapor pressure deficit of the air passing over the surface rather than by the input of net radiation. $R_{n}$, to the surface. Because $R_{a}$ is usually small in relation to $R_{c}$ in aerodynamically rough canopies, the ratio $R_{c}$ / $R_{a}$ is usually high (5-30). Therefore, the aerodynamic term in Eq. (3) is large in relation to the energy term (up to 20 times) (Stewart 1984). Consequently, for conifer forests, (2) can be simplified to the following (Jarvis and McNaughton 1986):

$$
\mathrm{LE}=\frac{\rho_{c_{p}}}{s+\gamma} \frac{\mathrm{VPD}}{R_{c}}
$$

Equation (4) indicates that the variables vapor pressure deficit (VPD) and canopy resistance $\left(\boldsymbol{R}_{c}\right)$ are of primary importance in regulating transpiration from a conifer forest stand. Therefore, for a given VPD, canopy resistance determines the partitioning of available energy into sensible and latent heat fluxes. Canopy resistance is a complex function of incident radiation, VPD, leaf water potential and finally leaf area index of the canopy. With all other factors held constant, an increase in leaf area results in a decreased $R_{c}$, because $R_{c}$ is a sum of resistances in different canopy layers working in parallel. Since $R_{c}$ directly controls the energy partitioning, the relation between canopy temperature, $T_{s}$, (the result of energy partitioning), and LAl should show similar trends. Therefore, we explored such a relationship using a remotely sensed canopy temperature, $T_{s}$, and canopy density (NDVI) as a proxy for $R_{c}$ for conifer forests.

\section{Methods}

This study was conducted on a mountainous $20 \mathrm{~km}$ $\times 25 \mathrm{~km}$ area enclosing Lubrecht Experimental Forest (LEF) of the University of Montana. Vegetation cover in the study area is almost complete, and predominantly conifer forests, with less than $10 \%$ of the area 


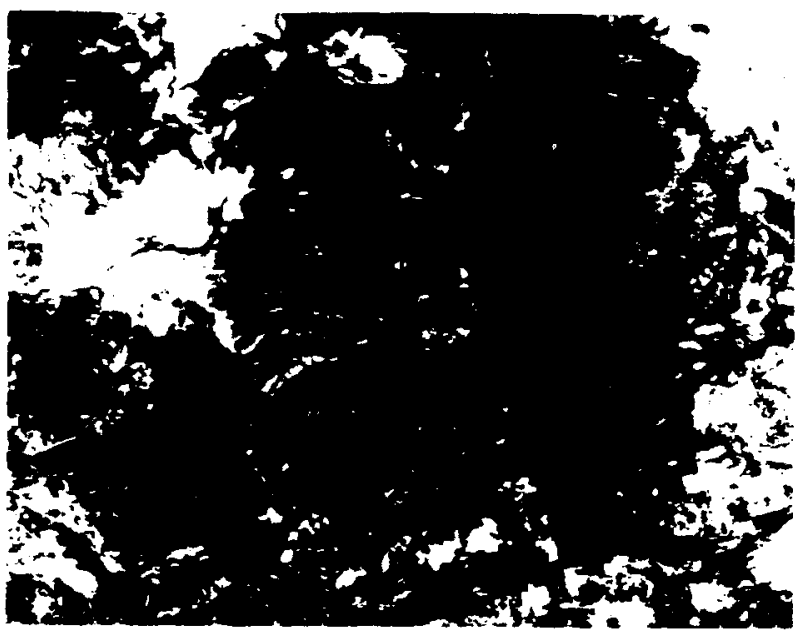

FIG. 1. A gray level map of the $20 \mathrm{~km} \times 25 \mathrm{~km}$ study area in Montana. showing general topography and density of vegetation. generated from Landsat / Thematic Mapper band 3 $(0.63-0.69 \mu)$ on $18 \mathrm{July} \mathrm{1984.} \mathrm{Density} \mathrm{of} \mathrm{vegetation,} \mathrm{predominantly} \mathrm{coniferous} \mathrm{forest.}$ increases with increasing grayness.

under nonconifer vegetation. Figure I shows a gray level map of the study area as seen in band $3(0.63-$ $0.69 \mu$ ) of the Landsat/Thematic Mapper. Darker areas represent higher canopy densities.

NOAA meteorological satellites have been found to be very useful for monitoring regional vegetation (Hayes 1985; Justice et al. 1985) and land-surface temperatures (Price 1984; Taconet et al. 1986b). The Advanced Very High Resolution Radiometer (AVHRR) on board the NOAA satellites has two wavelength bands for monitoring vegetation and three wavelength bands for surface temperature observations (Kidwell 1984). The synoptic coverage $(1.1 \mathrm{~km})$ and twice daily repeat cycle make these satellites particularly useful for regional ET studies.

In order to relate changes in the surface temperaturecanopy density relationship to canopy resistance, we acquired satellite image data from the NOAA-9/ AVHRR 1430 h overpass for 8 days during the summer of 1985 . We decided to use data from the $1430 \mathrm{~h}$ overpass only, because nighttime temperatures do not provide additional information on energy partitioning (Taconet et al. 1986b). Further, our aim was to show that midday surface temperatures are sensitive to canopy resistance. This differs from the soil moisture availability concept for bare soils which uses the daynight surface temperature amplitude (Carlson et al. 1981).

For each pass, digital data from the visible; channel 1 (RED, 0.55-0.68 $\mu$ ) and channel 2 (NIR, 0.72-1.1 $\mu)$ and thermal; channel $4(10.5-11.2 \mu)$ and channel $5(11.5-12.5 \mu)$, were extracted by displaying the imagery on a color monitor and with the aid of aerial photos. Data from a $20 \times 25$ pixel matrix enclosing LEF was extracted and used for further analysis.

\section{a. Leaf area index/canopy density}

Previous research has established significant correlations between canopy properties such as leaf area index (LAI) and IR/Red reflectance combinations (Tucker 1979; Asrar et al. 1984; Peterson et al. 1987). The underlying principle for such a relationship is as follows: Chlorophyll pigments in green leaves absorb radiation in the red wavelengths. Reflectance in red wavelengths are thus inversely related to the quantity of chlorophyll present in the canopy. On the other hand, near-infrared radiation is scattered by internal leaf structure, and is then either reflected or transmitted, allowing multiple layers of leaves to influence overall infrared reflectance. In the present study we chose the commonly used band combination. Normalized Difference Vegetation Index (NDVI), computed as follows:

$$
\mathrm{NDVI}=\frac{\mathrm{NIR}-\mathrm{RED}}{\mathrm{RED}+\mathrm{NIR}}
$$

On each day, for the $20 \times 25$ matrix NDVI was computed from channel 1 and 2 data. In a previous paper we found a high correlation between NDVI and estimated leaf area index (measure of canopy density). NDVI $=\mathrm{LN}(\mathrm{LAI} / 0.65) \times 0.34: R^{2}=0.88$, of these forests (Nemani and Running 1989). Spanner et al. (1987) reported similar results relating NDVI and leaf area index of conifer forests in the Pacific Northwest. Because a test of our original hypothesis requires only a range of canopy densities, we decided to use raw NDVIs without converting them into formal measures of canopy density or leaf area index. When required. LAI for each grid cell was estimated by inverting the above relation. LAI ranged between $2-9$ in the study area.

\section{b. Surface temperature $\left(T_{s}\right)$}

Surface temperature for each of the $20 \times 25$ pixels was calculated using the split-window technique (Prabhakara et al. 1974). For open water, Singh (1984) found that with root-mean-square errors less than $1^{\circ} \mathrm{C}$ over oceans,

$$
T_{s}=1.764 \mathrm{~Tb} 4-0.764 \mathrm{~Tb} 5+0.78
$$

where Tb4 and Tb5 are brightness temperatures from channel 4 and 5 from the AVHRR. Although this algorithm was not verified for land surfaces, it was selected for the following reasons: 1) it is simple compared to many atmospheric absorption models, 2) deviations between land and sea applications are probably small (Klassen and VanDen Berg 1985), because emissivities of water and vegetation (which is $95 \%$ water) agree remarkably well, and 3) for applications such as the present study, absolute accuracy is not as important as the relative seasonal trends. 
For each of the eight days, surface temperatures were plotted against NDVI, and changes observed in this relationship were related to simulated canopy resistance.

\section{c. Simulation of canōy resistance}

Canopy resistance was simulated using a forest ecosystem model, FOREST-BGC, which has been previously tested to produce reliable estimates of seasonal moisture extraction and canopy water stress in Montana forests (Donner and Running 1986; Nemani and Running 1988).

FOREST-BGC (biogeochemical cycles) is a process level ecosystem simulation model that calculates the cycling of carbon. water and nitrogen through forest ecosystems (Running and Coughlan 1988). The model requires daily input data of standard meteorological conditions, maximum-minimum air temperature, dew point. incident shortwave radiation and precipitation, and definition of key site and vegetation variables. The model calculates important processes of snowmelt, canopy interception and evaporation, transpiration and soil outflow of water: photosynthesis, growth and maintenance respiration, allocation, litter fall of carbon, and storage and mineralization of nitrogen. The model has a mixed-time resolution, with hydrologic, photosynthetic and maintenance respiration processes computed daily, and the other carbon and all nitrogen processes computed yearly. For this study the important parts of the model are the canopy resistance, evapotranspiration, hydrologic balance and canopy water stress. As a brief description, daily precipitation is routed to snowpack or soil dependent on air temperature, a canopy interception fraction based on LAI is subtracted and evaporated, and remaining water goes to a soil compartment where it is available for transpiration. Transpiration is calculated with a PenmanMonteith equation incorporating both radiation and vapor pressure deficit drivers for the process. The canopy conductance, inverse of canopy resistance, is a complex function of air temperature, vapor pressure deficit. incident radiation and leaf water potential. Air temperature below $0^{\circ} \mathrm{C}$ reduces canopy conductance to cuticular values, and is an important determinant of growing season length. Canopy conductance is linearly reduced to cuticular value when either daily vapor pressure deficits exceed $16 \mathrm{mb}$ or predawn leaf water potentials, estimated from soil water availability, decreases below $-1.65 \mathrm{M} \mathrm{Pa}$. Aerodynamic conductance was fixed at $0.2 \mathrm{~m} \mathrm{~s}^{-1}$ in the Penman-Monteith equation. More details can be found in Running and Coughlan (1988).

Meteorological data to run the model were collected from the central meteorological station at the headquarters of the LEF. On days when satellite imagery was acquired, hourly averages of air and dew point temperature, solar radiation and wind speed were also collected. The only site parameter required is soil water holding capacity, which was set at $23.5 \mathrm{~cm}$, and total leaf area index was set at 6 based on previous work at LEF (Donner and Running 1986; Running 1984). First, the model was run for the whole growing season. Then, for the eight chosen days, hourly averages of canopy conductance at the time of overpass $(1430 \mathrm{~h})$ were computed using the simulated predawn leaf water potentials from the whole growing simulation and measured hourly meteorological conditions. These canopy conductance values computed for a canopy with a total LAI of 6 were used for further analysis.

\section{d. Mapping canopy resistance}

We mapped canopy resistance for the study area on two days with contrasting water availability, 14 July (dry) and 6 August (moist). First, on each day regional canopy resistance (the entire study area) was computed from the regression relation between $\sigma$ and simulated canopy resistance. Then, for each grid cell canopy resistance was estimated by dividing the regional canopy resistance with leaf area index of that cell. Leaf area index for each cell was computed from NDVI using the relationship developed by Nemani and Running (1989) mentioned earlier.

\section{Results and discussion}

\section{a. Relation between surface temperature and NDVI}

Following the logic that $T_{s} /$ NDVI can be used as a proxy for $R_{c}$, the relation between surface temperature $\left(T_{s}\right)$ and NDVI for two days representing a dry (14 July) and a moist ( 6 August) case is illustrated in Fig. 2. There was a marked divergence in the $T_{s}$-NDVI

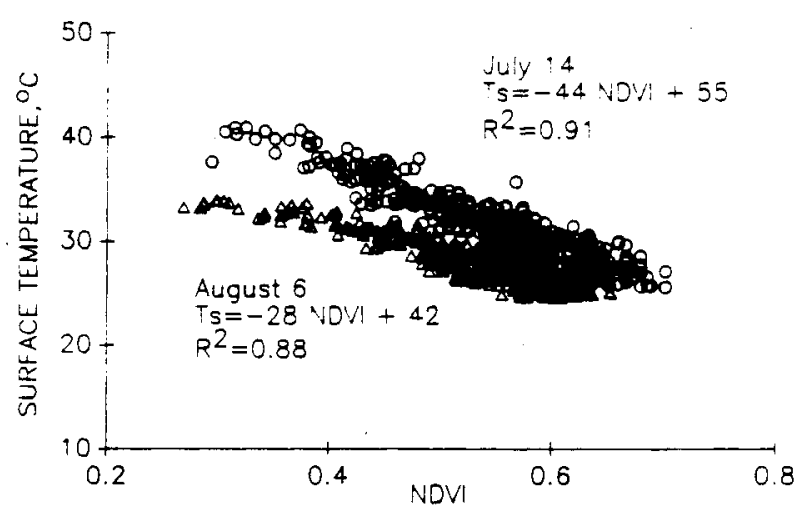

FIG. 2. Relation between surface temperature and Normalized Difference Vegetation Index, a measure of leaf area index, from the NOAA / AVHRR on 6 August and 14 July corresponding to the hypothetical cases shown in Fig. 1 for a $20 \times 25$ pixel area of conifer forest in Montana. Surface temperature was derived from split window technique using thermal AVHRR data (channeis 4 \& 5). NDVI was computed from RED and NIR data (channels 1 \& 2). The change in slope from 6 Auguat compared to 14 July indicates a change in canopy energy partitioning between the days. 
relationship between 14 July and 6 August. The 14 July period represents the case of low ET and high canopy resistance because of low soil moisture availability and high VPD (Table 1). No precipitation was received for 5 weeks-preceding 14 July. On the other hand, prior to 6 August, there was $3.2 \mathrm{~cm}$ of precipitation. Because of greater soil moisture availability, 6 August should be closer to the case of low canopy resistance and high ET. As expected, there was a strong negative relationship between surface temperature and NDVI on both days. Correlation coefficients for both cases were very high, 0.91 and 0.88 for 14 July and 6 August, respectively. However, the slope of the curves was different between the two days and followed expected trends. The slope of the $T_{s}$-NDVI curve, $\sigma$, changed from $-44\left({ }^{\circ} \mathrm{C} / \mathrm{NDVI}\right)$ on 14 July to -28 on 6 August, corresponding to the changes in simulated canopy resistances from $29 \mathrm{~s} \mathrm{~cm}^{-1}$ on 14 July to $11 \mathrm{~s}$ $\mathrm{cm}^{-1}$ on 6 August (Table 1). Since the meteorological conditions between the days were not very different $\left(T_{\text {air }}=27.7,26.5^{\circ} \mathrm{C}\right.$ and Relative humidity $\left.22 \%, 25 \%\right)$, the differences in simulated canopy resistance arose mainly from differences in moisture availability. This suggests that the behavior of $\sigma$ is similar to the moisture availability factor $(m)$ suggested by Carison et al. (1981) and Wetzel and Woodward (1987) for vegetated surfaces. The range of elevations in the study area, 1200$1800 \mathrm{~m}$, can produce differences in temperature of up to $4^{\circ} \mathrm{C}$, which is responsible for the small scatter in surface temperature at a given NDVI. As the same area was chosen on all eight days, the influence of this small scatter on NDVI and surface temperature relation should be similar throughout the season. Although a linear relationship fits very well for the data in this study, we do not think it will be sufficient in other cases, because beyond a certain LAI, $\boldsymbol{R}_{c}$ does not decrease with LAI at the same rate and surface temperatures come into equilibrium with air temperatures (Fig. 2).

Analysis of the two contrasting scenarios does suggest that the slope of $T_{s}$-NDVI curve, $\sigma$, is sensitive to changes in resistance exhibited by the surface to ET. Given that, $\sigma$ was computed for all the eight days during the growing season to see if it could represent the seasonal changes in $R_{c}$.

\section{b. Seasonal trends in canopy resistance}

Figures $3 a-c$ show seasonal trends in precipitation received, predawn leaf water potential (a measure of canopy water stress), and canopy resistance at Lubrecht Experimental Forest. The 1985 growing season was characterized by a brief wet period during the end of May followed by an unusually long ( 5 weeks) dry spell during June and July. August and September were relatively wet compared to 20 -yr averages. Simulated predawn leaf water potentials directly reflect the amount of soil moisture available to plants, and closely followed
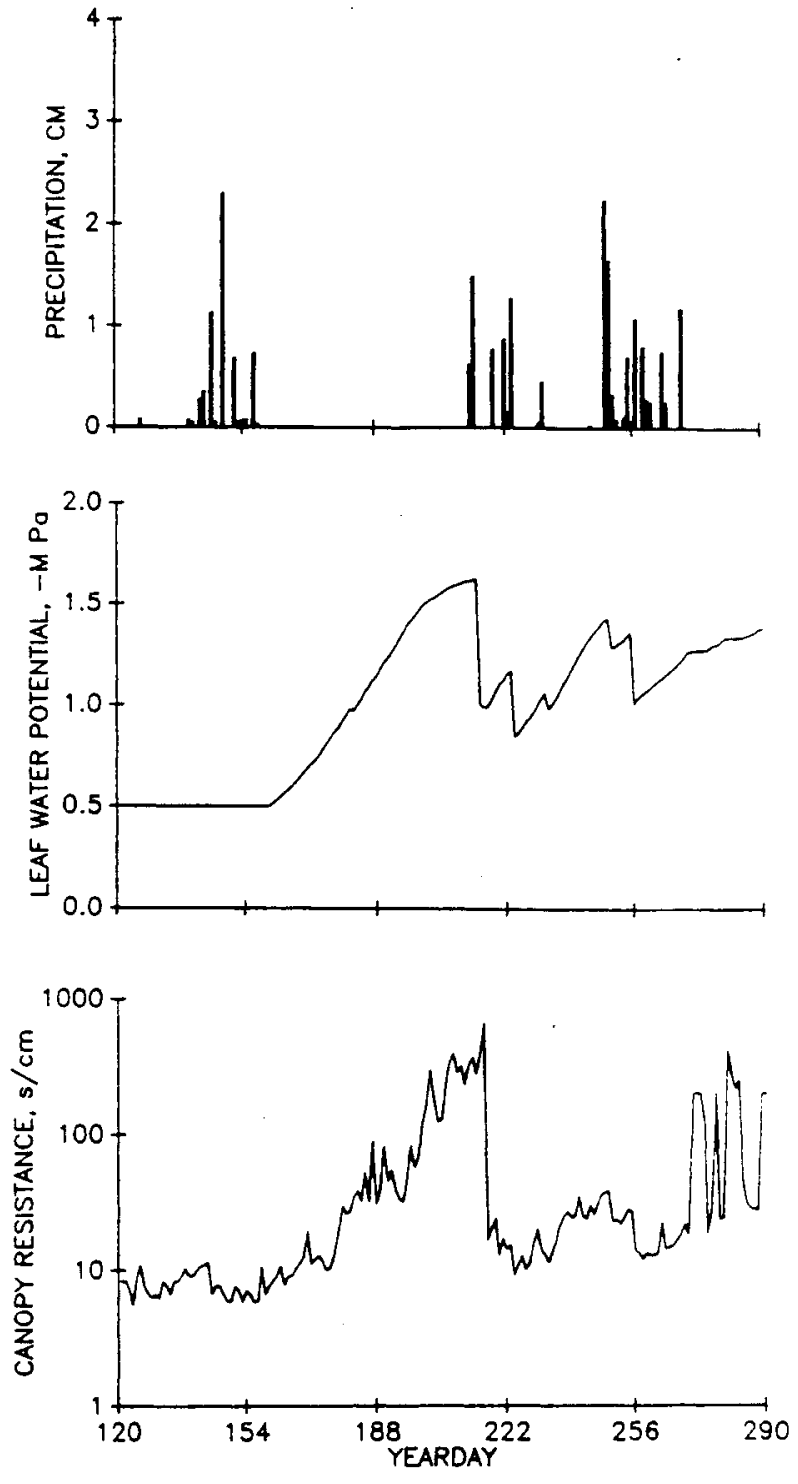

FIG. 3. Seasonal trends in precipitation (a), predawn leaf water potentials. a measure of canopy water stress (b), and daily average canopy resistance (c) simulated by FOREST-BGC at Lubrecht Experimental Forest. Montana for a stand of total $\mathrm{LAI}=6$. soil water capacity $=23.5 \mathrm{~cm}$ during 1985 .

the precipitation patterns during the growing season. Corresponding with the dry spell, the forest endured lowest leaf water potentials during the month of July. The decreasing trend in leaf water potentials was broken by rainfall received during the first week of August. The precipitation during the first two weeks of August replenished the soil considerably, thereby bringing leaf water potentials from $-1.6 \mathrm{M} \mathrm{Pa}$ on 31 July to -0.8 $\mathrm{M} \mathrm{Pa}$ on 15 August. Leaf conductance reflects complex interactions in the Soil-Plant-Atmospheric-Continuum and determines the water losses and $\mathrm{CO}_{2}$ uptake by the canopies. Therefore, it is the most important measure of canopy activity. The seasonal trends in 


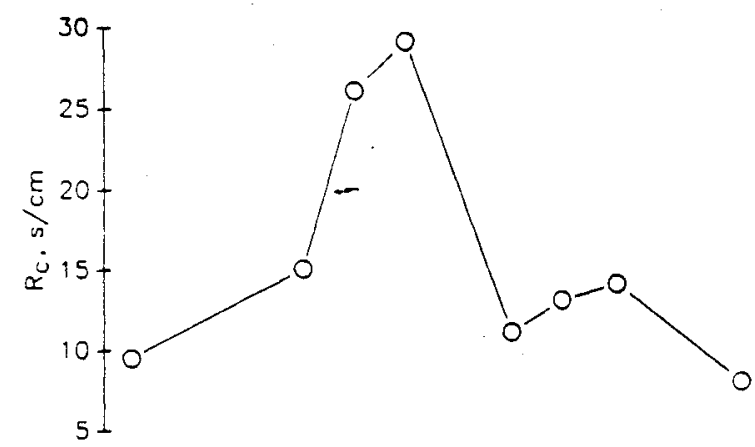

moderate VPD allowed the canopy resistance to return to an intermediate level. The hourly average $R_{c}$ computed for the eight days at the time of the satellite overpass represented the three periods fairly accurately (Fig. 4).

\section{$c$. Relation between $\sigma$ and $R_{c}$ during the growing season}

Given that $\sigma$ is sensitive to changes in canopy activity on the two days shown in Fig. 2, we plotted $\sigma$ and $R_{c}$ as a function of yearday (Fig. 4) to find out whether the changes in $\sigma$ can represent the seasonal $R_{c}$ activity cycle. Further details on $\sigma$ and $R_{c}$ along with the as-

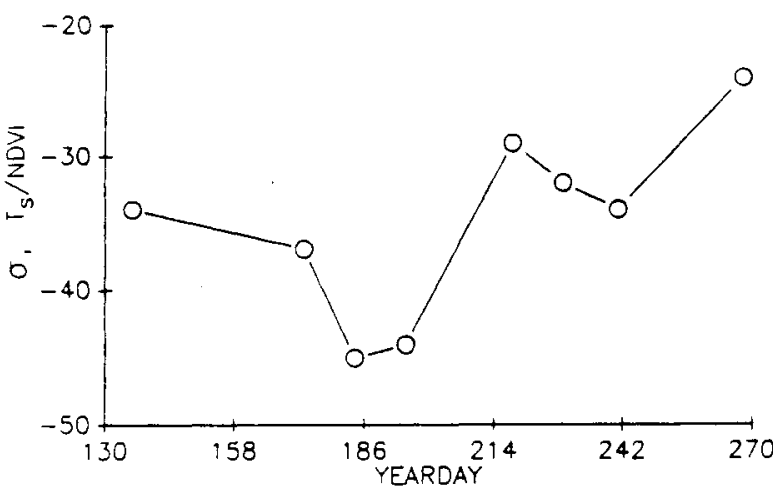

FIG. 4. Relation between simulated $1430 \mathrm{~h}$ canopy resistance from FOREST-BGC and the slope of surface temperature and NDVI, $\sigma$, derived from the NOAA / AVHRR on eight days during the summer of 1985. Each point describes the slope. as in Fig. 3, of a scattergram of the $20 \times 25$ pixel study area.

canopy resistance (Fig. $3 \mathrm{c}$ ) show three distinct periods of canopy activity: 1) Late spring and early summer period, with adequate soil moisture and low vapor pressure deficits (VPD), average canopy resistance was low during this period: 2) Midsummer, high VPD and lowest soil moisture (low LWP) brought the vegetation activity to be almost negligible: and 3) Late summer, recovery in soil moisture from precipitation along with sociated soil moisture and weather conditions for the eight test days during the growing season are given in Table 1. Canopy activity through the three periods discussed earlier was closely tracked by $\sigma$, evident from its values in May, July and August (Table 1 ). An interesting case in point is 29 September, because both the simulated hourly average canopy resistance $(8 \mathrm{~s}$ $\left.\mathrm{cm}^{-1}\right)$ and $\sigma(-24)$ had the lowest values on 29 September. Low VPD combined with good soil moisture availability conditions allowed the canopies to spend most of the incident radiation at latent heat flux (as opposed to sensible heat flux) on this day.

Given that the seasonal patterns of $\sigma$ and $R_{c}$ appeared closely related, we plotted $R_{c}$ as a function of satellite derived $\sigma$ (Fig. 5). A nonlinear relationship emerged where $R_{c}$ is becoming asymptotic beyond $20 \mathrm{~s} \mathrm{~cm}^{-1}$. It has been reported that for $R_{c}$ values beyond $20 \mathrm{~s}$ $\mathrm{cm}^{-1}$, transpiration from the canopy is usually negligible ( Jarvis and Leverenz 1983). Therefore, $R_{c}$ values beyond $20 \mathrm{~s} \mathrm{~cm}^{-1}$ would make little additional difference to the partitioning of energy between sensible and latent heat.

Figure 6 illustrates the differences in canopy resistance estimated from $\sigma$ across the study area on two days of differential moisture availability. Canopy resistance is high ( $\left.30-60 \mathrm{~s} \mathrm{~cm}^{-1}\right)$ on 14 July across the entire study area reflecting the drought conditions dur-

TABLE 1. Seasonal trends of surface temperature $(T$,$) and NDVI relationship along with measured/simulated soil-plant-atmospheric$ conditions at $1430 \mathrm{~h}$ on eight test days during 1985.

\begin{tabular}{|c|c|c|c|c|c|c|c|}
\hline \multirow[b]{2}{*}{ Date } & \multirow[b]{2}{*}{$\begin{array}{l}\text { Radiation } \\
\left(\mathrm{W} \mathrm{m}^{-2}\right)\end{array}$} & \multirow{2}{*}{$\begin{array}{l}\text { Measured } \\
\text { air tem. } \\
\left({ }^{\circ} \mathrm{C}\right)\end{array}$} & \multirow[b]{2}{*}{$\begin{array}{l}\text { VPD } \\
(\mathrm{k} \mathrm{Pa})\end{array}$} & \multicolumn{2}{|c|}{ FOREST-BGC simulation } & \multirow[b]{2}{*}{$\begin{array}{l}T_{s} \text { vs. NDVI } \\
\text { relationship }\end{array}$} & \multirow[b]{2}{*}{$R^{2}$} \\
\hline & & & & $\begin{array}{l}\text { Leaf water pot. } \\
(-\mathrm{M} \mathrm{Pa})\end{array}$ & $\begin{array}{l}\text { Canopy res. } \\
\left(\mathrm{s} \mathrm{cm}^{-1}\right)\end{array}$ & & \\
\hline $\begin{array}{l}16 \text { May } \\
22 \text { Jun } \\
03 \text { Jul } \\
14 \text { Jul } \\
06 \text { Aug } \\
17 \text { Aug } \\
29 \text { Aug } \\
25 \text { Sep }\end{array}$ & $\begin{array}{l}750 \\
850 \\
820 \\
850 \\
730 \\
700 \\
630 \\
450\end{array}$ & $\begin{array}{l}20.0 \\
24.0 \\
30.5 \\
27.7 \\
26.6 \\
24.0 \\
26.0 \\
13.3\end{array}$ & $\begin{array}{l}1.45 \\
1.90 \\
2.43 \\
2.40 \\
2.12 \\
1.84 \\
2.30 \\
0.90\end{array}$ & $\begin{array}{l}0.50 \\
0.75 \\
1.05 \\
1.30 \\
1.00 \\
0.95 \\
1.10 \\
1.05\end{array}$ & $\begin{array}{r}9.5 \\
15.0 \\
26.0 \\
29.0 \\
11.0 \\
13.0 \\
14.0 \\
8.0\end{array}$ & $\begin{array}{l}T_{s}=-34 \mathrm{NVDI}+47 \\
T_{s}=-37 \mathrm{NDVI}+53 \\
T_{3}=-45 \mathrm{NDVI}+60 \\
T_{3}=-44 \mathrm{NDVI}+55 \\
T_{1}=-28 \mathrm{NDVI}+42 \\
T_{3}=-32 \mathrm{NDVI}+41 \\
T_{3}=-34 \mathrm{NDVI}+53 \\
T_{s}=-24 \mathrm{NDVI}+28\end{array}$ & $\begin{array}{l}0.73 \\
0.78 \\
0.78 \\
0.91 \\
0.88 \\
0.85 \\
0.77 \\
0.74\end{array}$ \\
\hline
\end{tabular}




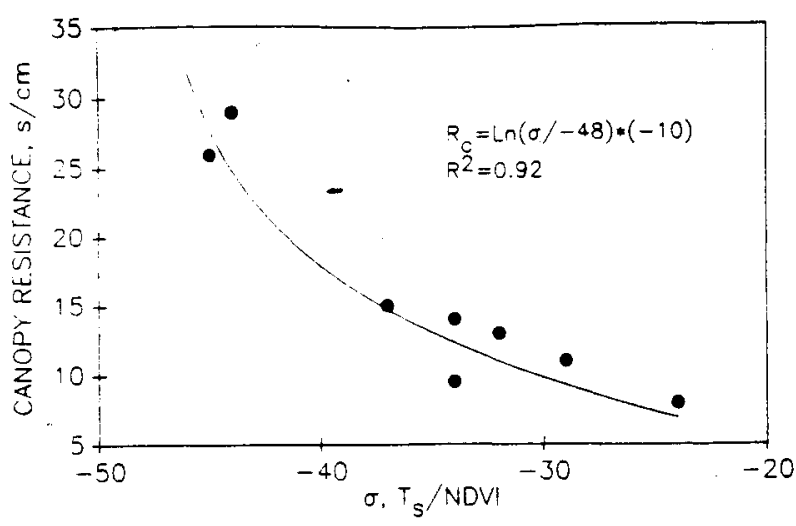

FIG. 5. The regression relationship between simulated canopy resistance and slope of surface temperature and NDVI, $\sigma$, at $1430 \mathrm{MST}$ overpass time of the NOAA/AVHRR. for eight days during the summer of 1985 . for the $20 \times 25$ pixel forested area.

ing June and July of 1985 . On the other hand, canopy resistance dropped to $10-20 \mathrm{~s} \mathrm{~cm}^{-1}$ on 6 August following rainfall. Areas of high canopy density located in the middle of the study area generally showed low canopy resistance on both days, while low density areas showed the greatest amount of change in resistance between the two days. Because interception losses are low for low density areas more precipitation gets through to the soil, allowing a larger recovery in overall resistance.

We believe that $\sigma$ is responding to the total resistance to ET at the surface. The surface resistance may include aerodynamic and canopy resistances as well as resistance to vapor diffusion through soil. However, given these study sites and canopy characteristics, we assume $R_{c}$ to make the highest contribution to the total surface resistance.

\section{Conclusions}

The slope of $T_{s}$-NDVI curve, $\sigma$, appears to be generally capable of showing changes in canopy resistance of conifer forests. The physical realism behind $\sigma$, energy partitioning between sensible and latent heat fluxes, and the case of computation through remote sensing seem to strengthen its usefulness in regional ET research. Accurate estimates of either canopy resistance or soil moisture availability may not be possible from this approach because of the complexities involved in remote sensing of canopy density as well as surface temperature. However, we believe $\sigma$ can be used as a scaling factor where parameterization of canopy activity is needed on a regional scale. For example, $\sigma$ could serve as a useful alternative to Priestley-Taylor's alpha factor and improve regional ET estimates considerably, and it could be related to a Bowen ratio for regional energy budgets. Also, $\sigma$ may be used to improve global net primary production estimates from integration of NDVI over a growing season. Further, $\sigma$ could be used as a stress index to account for nonoptimal conditions, while integrating NDVI (Running 1986).

The relationship between $T_{5}$ and NDVI could also provide useful information about the synoptic state of the atmosphere: air temperature and vapor pressure deficit. For example, air temperatures can be estimated from the satellite temperatures by choosing pixels with highest NDVI values. The possibility of complete canopy closure in such pixels along with the strong coupling of conifer forests to the atmosphere allows the determination of air temperatures (Sader 1986). For example, on both 14 July and 6 August. air temperatures can be reasonably approximated from the $T_{s} /$ NDVI curves (Fig. 2). Similarly, rational estimates of VPD might be derived from $\sigma$ as they seemed to show similar trends (Table 1). This may be unique to conifers, as VPD exerts strong control on stomatal physiology of conifer needles.

Approximation of surface resistance through $\sigma$ has important implications in regional ET studies where

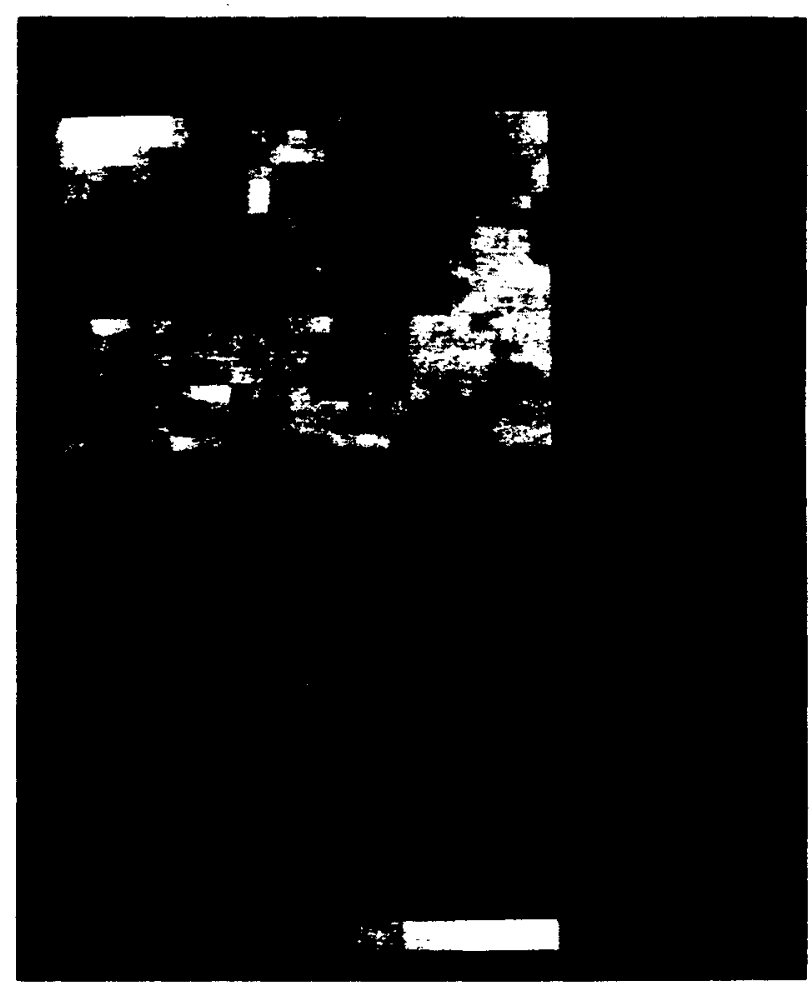

FIG.6. Map showing canopy resistance across the study area, computed using the relationship between surface temperature and NDVI, on two days with contrasting moisture availability, $14 \mathrm{July}$ ( dry, simulated leaf water potential of $-1.5 \mathrm{M} \mathrm{Pa}$ ) and 6 August (moist. simulated leaf water potential of $-0.8 \mathrm{M} \mathrm{Pa}$ ). Estimated canopy resistance ranged from $30-50 \mathrm{~s} \mathrm{~cm}^{-1}$ (high brightness values) on $14 \mathrm{July}$ compared to $10-20 \mathrm{~s} \mathrm{~cm}^{-1}$ (low brightness values) on 6 August. 
parameterization of surface resistance is extremely difficult over large complex areas. Because of the very complex nature of water flow through plants and of the response of stomata to a restricted supply of water. the specification of surface wetness for atmospheric models is very difficult 1 Monteith 1981). Either fixed values of surface resistance (Carpenter 1977) or minimum values of surface resistance that change seasonally (Wales-Smith and Arnott 1979) were used to compute regional evaporation in mesoscale models of the atmosphere. However. a more direct relationship between surface resistance and soil water deficits has been sought for several years (Monteith 1981). We believe $\sigma$ reflects such a relationship and would be a useful tool in regional evaporation research.

Acknowledgments. Funding for this research was provided by the National Aeronautics and Space Administration, Earth Sciences and Applications Division, Grant NAGW-952, Joint Research Interchange NCA 2-138 and NCA 2-27 from NASA/Ames Research Center, Moffet Field, California, and McIntire-Stennis funding to the University of Montana. We thank Drs. Darshan Kang, Donald Potts, Ronald Wakimoto and Hans Zuuring for reviews of the draft manuscript.

\section{REFERENCES}

Abdellaoui, A., F. Becker and E. Olory-Henchinger.' 1986: Use of Meteosat for mapping thermal inertia and evapotranspiration of a limited region of Mali. J. Climate .Appl. Meteor.. 25(11), $1489-1506$.

Asrar. G., M. Fuchs. E. T. Kanemasu and J. L. Hatfield. 1984: Estimating absorbed photosynthetic radiation and leaf area index from spectral reflectance in wheat. Agron J.. 76, 300-306.

Brutsaer. W.. 1986: Catchment-scale evaporation and atmospheric boundary layer. Water Res. Research. 22(9), 39-46.

Carlson. T. N., F. E. Boland. J. K. Dodd and S. G. Benjamin. 1981: Satellite estimation of the surface energy balance. moisture availability and thermal inertia. J. Appl. Meteor., 20,67-87.

Carpenter. K. M.. 1977: Surface exchanges in a mesoscale model of the atmosphere. Met. Off. 11 Tech. Note 96, Meteorological Office, U.K.

Cheevasuvit, F.. O. Taconet. D. Vidal-Madjar and M. Maitre. 1985 Thermal structure of an agricultural region as seen by NOAA7 AVHRR. Remote Sens. Environ. 17, 153-163.

De Bruin. H. A. R.. 1983: A model for the Priestley-Taylor parameter. J. Climate Appl. Meteor.. 22, 572-578.

Deardorff, J. W., 1978: Efficient prediction of ground surface temperature and moisture with inclusion of a layer of vegetation. J. Geophys. Res., 83(4), 1889-1903.

Donner, B. L., and S. W. Running, 1986: Water stress response after thinning Pinus contona stands in Montana. Forest Sci., 32 614 625 .

Goward, S. N., G. D. Cruickshank and A. S. Hope, 1985: Observed relation between thermal emission and refiected spectral radiance of a complex vegetated landscape. Remote Sens. Environ., 18, $137-146$.

Gurney, R., and P. J. Camillo, 1984: Modelling daily evapotranspiration using remotely sensed data. J. Hydrol., 69, 305-324.

Hayes, L., 1985: The current use of TIROS-N series of meteorological satellites for land-cover studies. Int. J. Remote Sens., 6(1), 3545.
Idso, S. B., T. J. Schmugge. R. D. Jackson and R. J. Reginato. 1975 The utility of surface temperature measurements for the remote sensing of surface soil water status. J. Geophys. Res. $\mathbf{8 0}(21)$, 3044-3049

Jarvis. P. G.. and J. L. Leverenz. 1983: Productivity of temperate. deciduous and evergreen forests. Encyclopedia of Plant Physlology, Vol I2D. Physiological Ecology. O. Lang, P. Nobel. C. Osmond, $H$. Ziegler. Eds.. Springer-Verlag.

- and K. G. McNaughton. 1986: Stomatal control of transpiration. Scaling up from leaf to region. $A d v$. Ecol. Res.. 15. $1-49$.

Justice, C. J.. J. Townshend. B. Holben and C. Tucker. 1985: Analysis of the phenology of global vegetation using meteorological satellite data. Int. J Remote Sens., 6, 1271-1318.

Kidwell, K. B., 1984: NOAA polar orbital data users guide (TIROSN. NOAA-6, -7, -8). NOAA National Climate Center. Washington $D C$.

Klassen. W.. and W. VanDenberg. 1985: Evapotranspiration derived from satellite observed surface temperatures. $J$. Climate and Appl. Meteor. 24, 412-424.

McNaughton. K. G.. and P. G. Jarvis, 1983: Predicting effects of vegetation changes on transpiration and evaporation. Hater Deficits and Plant Growth. Vol. 17, T. T. Kozlowskii. Ed.. Academic Press.

Monteith. J. L.. 1981: Evaporation and surface temperature. $Q J$ Roy. Meteor. Soc. 107, 1-27.

Nemani, R. R.. and S. W. Running. 1989: Testing a theoretical climate-soil-leaf area hydrologic equilibrium of forests using satellite data and ecosystem simuiation. Agric. and For. Meteor. 44. 245-260.

Peterson. D. L.. M. A. Spanner. S. W. Running and K. B. Teuber. 1987: Relationship of Thematic Mapper Simulator data to leaf area index of temperate coniferous forests. Remote Sens. Environ., 22, 323-341.

Prabhakara. C.. G. Dalu and V. G. Kunde. 1974: Estimation of sea surface temperature from remote sensing in the 11 micrometer to 13 micrometer window region. J. Geophy's. Res., 79, 50395044.

Price. J., 1982: On the use of satellite data to infer surface fluxes at meteorological scales. J. Appl. Meteor. 21, $1111-1122$.

Price. J. C., 1984: Land surface temperature measurements from the split window channels of NOAA-7 Advanced Very High Resolution Radiometer. J. Geophys. Res., 89, 7231-7237.

Priestley, C. H. B., and R. J. Taylor, 1972: On the assessment of surface heat flux and evaporation using large-scale parameters. Mon. Wea. Rev., 100, 81-92.

Rasool. S., and H. Bolle, 1984: ISLSCP: International satellite landsurface climatology project. Bull. Amer. Meteor. Soc. 65(2), 143-144.

Running, S. W., 1984: Microclimate control of forest productivity: Analysis by computer simulation of annual photosynthesis/ transpiration balance in different environments. Agric. For Meteor., 32, 267-288.

—, 1986: Global primary production from terrestrial vegetation: Estimates integrating satellite remote sensing and computer simulation technology. Sci. Total Environ., 56, 233-242.

- and J. C. Coughlan. 1988: A general model of forest ecosystem processes for regional applications. Ecol. Modeling, 42, 125154.

Sader, S. A., 1986: Analysis of effective radiant temperatures in a Pacific Northwest forest using thermal infrared multispectral scanner data. Remote Sens. Environ., 19, 105-115.

Sequin, B., and B. Itier, 1983: Using midday surface temperature to estimate daily evaporation from satellite thermal IR data. Int. J. Remote Sens., 4, 371-383.

Singh, S. M.. 1984: Removal of atmospheric effects on a pixel by pixel basis from the thermal infrared data from instruments on sateflites. Int. J. Remote Sens., 5, 161-183.

Soer, G. J. R., 1980: Estimation of regional evapotranspiration and 
soil moisture conditions using remotely sensed crop surface temperatures. Remote Sens. Environ., 9. 27-36.

Spanner, M. A., D. L. Peterson, S. W. Running and L. Pierce. 1987: The relationship of AVHRR data to the leaf area index of western coniferous forests. Space Life Sciences Symp.: Three Decades of Life Sciences Research in Space. Washington. DC.

Stewan. J. B., 1984: Measusement and prediction of evaporation from forested and agricultural catchments. Agric. Water. Management. 8, 1-28.

Taconet. O., R. Bernard and D. Vidal-Madjar. 1986a: Evapotranspiration over an agricultural region using a surface flux / temperature model based on NOAA-A VHRR data. J. Climate Appl. Meteor., 25(3), 284-307.

—. T. Carison, R. Bernard and D. Vidal-Madjar, 1986b: Evaluation of a surface/vegetation parameterization using satellite measurements of surface temperature. J. Climate .Appl. . Meteor.. 25. 1752-1767

Thom, A. S., 1975: Momentum, mass and heat exchange in plant communities. Vegetation and the Atmosphere. J. L. Monteith. Ed. Academic Press.

Tucker, C. J. 1979: Red and photographic infrared linear combinations for monitoring vegetation. Remote Sens. Environ., 8. 127-150.

Wales-Smith, B. C., and J. A. Arnott, 1979: The evaporation calculation system used in the United Kingdom (MORCES) Casebook on Operational Assessment of Evaporation. WMO.

Wetzel. P. J., and D. Atlas. 1983: Inference of soil moisture from geosynchronous satellite infrared observations. Proc. Sixth Conf Biometeorology and Aerobiology. Amer. Meteor. Soc.. 178-181. , and R. H. Woodward, 1987: Soil moisture estimation using GOES-VISSR Infrared data: A case study with a simple statistical method. J. Climate Appl. Meteor., 26, 108-117.

Whitehead, V.S., W. R. Johnson and J. A. Boatright. 1986: Vegetation assessment using combination of visible. near-infrared. and thermal-IR AVHRR data. IEEE Trans. Geosci. Remote Sens. GE. 24(1), 107-112. 